\title{
Effect of Ovsynch Estrus Synchronization Protocol on Fertility in Crossbred Ewes
}

\author{
Vinay Yadav ${ }^{1 *}$, Ramesh Kumar Chandolia ${ }^{1}$, Ravi Dutt ${ }^{1}$, Amarjeet Bisla ${ }^{2}$, Gitesh Saini ${ }^{1}$, \\ Gyan Singh ${ }^{3}$ and L.C. Ranga ${ }^{4}$ \\ ${ }^{1}$ Department of Veterinary Gynaecology and Obstetrics, Lala Lajpat Rai University of Veterinary and Animal Sciences (LUVAS), \\ Hisar, Haryana, INDIA \\ ${ }^{2}$ Division of Animal Reproduction, ICAR-Indian Veterinary Research Institute (IVRI), Izatnagar, Bareilly, UP, INDIA \\ ${ }^{3}$ Department of Veterinary Clinical Complex, LUVAS, Hisar, Haryana, INDIA \\ ${ }^{4}$ Central Sheep Breeding Farm, Hisar, Haryana, INDIA \\ *Corresponding author: V Yadav; E-mail: vinayrao30693@gmail.com
}

Received: 18 Feb., 2020

Revised: 16 June, 2020

Accepted: 06 July, 2020

\begin{abstract}
The present study was designed to test the comparative efficacy of Ovsynch estrus synchronization protocols during two different phases's i.e. breeding and out-of-breeding season in crossbred ewes. During both phases a total of 60 ewes were randomly divided into four groups ( $\mathrm{n}=15$ in each group) viz. Group I (Control out-of-breeding season), II (Treatment out-ofbreeding season), III (Control breeding season) and IV (Treatment breeding season). The Ovsynch protocol (Group II and IV) consisted of buserelin acetate on day 0 , cloprostenol sodium on day 5 and buserelin acetate on day 7 intramuscular (im). Blood sampling was carried out for estimation of plasma progesterone concentration in due course of study. Trans-rectal real-time B-mode ultrasonography (USG) was done for early pregnancy diagnosis at day 25 post-mating with reconfirmation on day 45. The results of the present study showed that the Ovsynch protocol was almost equally effective in induction of estrus resulting in better pregnancy rate and subsequent fertility during both seasons. The progesterone concentration did not vary significantly among all groups $(\mathrm{P}<0.05)$ on day 14,25 and 45 post-mating. Thus, the Ovsynch protocol could be advised for improvement of reproductive efficiency during breeding as well as out-of-breeding season in crossbred ewes throughout the year.
\end{abstract}

\section{HIGHLIGHTS}

(0 Ovsynch protocol is equally effective for estrus induction in breeding and out-of-breeding season in ewes.

(0 Ovsynch protocol could improve reproductive efficiency in out-of-breeding season in ewes.

Keywords: Sheep, Estrus synchronization, Ovsynch, GPG, Ultrasonography

The reproductive seasonality is one of the constraints in achieving higher reproductive efficiency in ewes. Ovarian cyclical activity is a result of interaction and coordinated effect of multiple hormones in the biological system. The cyclical reproductive activities are affected by the hormones at various stages which enable the concept of using various exogenous hormones either alone or in combination for the estrus synchronization and improvement of reproductive efficiency in ewes (Abecia et al., 2011). The Ovsynch/GPG (GnRH-PGF $2 \alpha-G n R H)$ protocol of estrus synchronization in ewes consists of an injection of $\mathrm{GnRH}$ on the starting day of protocol (day
0 ) to initiate the ovulation of dominant follicles, followed by an injection of $\mathrm{PGF}_{2} \alpha$ on day 5 or day 7 to induce luteolysis, followed by injection of GnRH on day 7 or day 9 and timed AI or mating of animals on observed estrus (Ashmawy, 2011). In a study by Maracek et al. (2009) 50 ewes were subjected to modified GPG protocol (0-5-7), 45 induced to estrus and 24 produced lambs. However,

How to cite this article: Yadav, V., Chandolia, R.K., Dutt, R., Bisla, A. Saini, G., Singh, G. and Ranga, L.C. (2020). Effect of ovsynch estrus synchronization protocol on fertility in crossbred ewes. J. Anim. Res., 10(4): 543-549.

Source of Support: None; Conflict of Interest: None (c) 
contrasting results has been observed by different workers with the use of GPG protocol on the synchrony of ovulation in ewes (Ali et al., 2009; Hashem et al., 2015). But, as per the available literature is concerned, the studies about the efficacy of Ovsynch estrus synchronization protocol in ewes are meager in the tropical and semitropical areas like India. The protocol seem to be cheaper and does not require the expertise to be performed so could be implicated in field conditions for improvement in the reproductive efficiency in sheep. The hypothesis of the present study was that the use of cheaper estrus synchronization protocols (Ovsynch) in crossbred ewes shall improve the reproductive performance in terms of fertility during breeding as well as out-of-breeding season to enable better economic returns throughout the year irrespective of seasonality.

\section{MATERIAL AND METHODS}

\section{Site and time of study}

The study was conducted at Central Sheep Breeding Farm (latitude $29^{\circ} \mathrm{N}$ and longitude $75^{\circ} \mathrm{E}$ with average elevation of $215 \mathrm{~m}$ from the sea level), Hisar, (Haryana), India. The institute is located at the place where mainly sub-continental climatic conditions are present with a significant annual variation in the temperature (summers and winters). The study was conducted for a period of one year in two phase's i.e out-of-breeding season (MayJune; summer) and breeding season (September-October; autumn). The prior permission from the institutional animal ethics committee (IAEC) was taken for conducting the experiment.

\section{Experimental animals and design of study}

A total of sixty (30during each season) crossbred (Nali $\times$ Rambuillet) ewes aged between 3-5 years, weighing $34-45 \mathrm{~kg}$ and fifteen healthy crossbred (Nali $\times$ Rambuillet) rams aged 3-4 years, weighing 50-60 kg, were selected on the basis of their previous breeding history with absence of any reproductive illness. The animals had access to natural grazing area for most of the day with supplementary concentrate feeding, ad libitum drinking water and mineral licks available under iso-managerial conditions at in-door during night. Experimental animals were randomly divided into four groups' viz. one control and one treatment group during each season having 15 animals in each group. Group I and IINB were during outof-breeding season while Group III and IV were during breeding season. Group II and IV received Ovsynch protocol $\left\{4 \mu \mathrm{g}\right.$ buserelin acetate $\left(\right.$ Gynarich ${ }^{\circledR}$-Intas, India) im, $125 \mu \mathrm{g}$ cloprostenol sodiumim (Vetmate ${ }^{\circledR}$-Cargill, India) and $4 \mu \mathrm{g}$ buserelin acetate im (Gynarich ${ }^{\circledR}$-Intas, India) on day 0 (start of treatment), 5 and 7 , respectively\} (Fig. 1). The animals under breeding season were presynchronized with double PG (Prostaglandin) protocol at interval of 10 days with $125 \mu \mathrm{g}$ cloprostenol sodium im (Vetmate ${ }^{\circledR}{ }_{-}$-Cargill, India) to bring animals at same stage of estrous cycle and were selected $4^{\text {th }}$ day post second PG injection. The animals under Group I and III were kept as control and were not subjected to any treatment. Thereafter, ram parading for estrus detection was carried out in all groups and the ewes were allowed for natural mating to occur until next $96 \mathrm{~h}$.

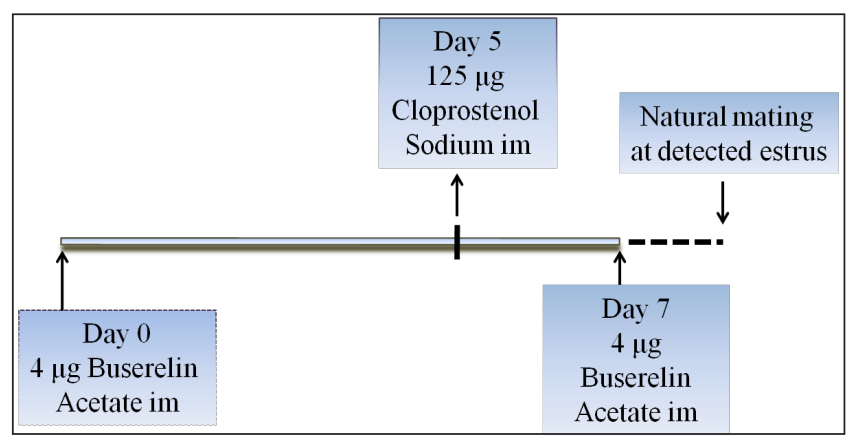

Fig. 1: Ovsynch estrus synchronization protocol consisting of GnRH-PGF $2 \alpha$-GnRH injections on day 0 (start of treatment), 5 and 7 , respectively

\section{Data collection}

The ewes were detected in estrus via ram parading and behavioral signs. The time interval between the end of treatment and onset of estrus (h) as well as estrus duration (h) of all the ewes detected in estrus was recorded. The estrus induction rate was calculated by number of ewes detected in estrus/total number of ewes under treatment in each group multiplied by 100 . Also, pregnancy rate at day 25 and 45 post-mating was calculated by number of ewes detected pregnant/total number of ewes mated in each group multiplied by 100 . The ewes in out-ofbreeding and breeding season groups lambed during 
November-December and March-April, respectively and the lambing data was recorded. The fertility or lambing rate was calculated as number of ewes lambed/total number of animals in breeding group multiplied by 100 . Furthermore, percent prolificacy was calculated as total number of lambs born in each group/number of ewes lambed in the group multiplied by 100 . Moreover, the fecundity percentage was calculated as number of lambs born/number of ewes mated multiplied by 100 .

\section{Plasma progesterone analysis}

For estimation of plasma progesterone (P4) (ng/mL) of ewes that underwent treatment, blood sampling was carried out in the morning (9-11 a.m.) via jugular venipuncture: at the start of treatment (time one), 14, 25 and 45 days postmating (time two, three and four, respectively). The blood samples were collected in EDTA vials and subjected to centrifugation ( $3000 \mathrm{rpm}$ for $15 \mathrm{~min}$ at $4{ }^{\circ} \mathrm{C}$ ). The plasma was separated and stored at $-20^{\circ} \mathrm{C}$ till further $\mathrm{P} 4$ analysis. Plasma P4 concentration was assessed via ELISA (enzyme linked immune-sorbent assay) method with Plasma P4ELISA kit (CALBIOTECH, USA) using Read Well Touch ELISA Plate Analyzer (Benchtop ${ }^{\circledR}$, USA).

\section{Ultrasonography (USG)}

Real-time B-mode USG (Sonoscape S6, Portable USG machine, China) using trans-rectal probe at 5-6 MHz frequency was carried out at the start of the experiment for selection of non-pregnant animals. Further, USG was done on day 25 and 45 post-mating for early pregnancy diagnosis and assessment of embryonic mortality, respectively.

\section{STATISTICAL ANALYSIS}

The obtained data from the all treatment groups (both in out-of-breeding and breeding season) was statistically analyzed using GraphPad Prism version 8.0.1 (244) software. The normal distribution of obtained data was evaluated via Microsoft Excel (2013) software and the majority of data was found fairly symmetrical (Skewness 0.5 to -0.5 ) while, some data was moderately skewed (Skewness 1.0 to -1.0 ) which might be due to small sample size in some parameters. The data with high skewness $(>1.0$ and $<-1.0)$ was not considered for the statistical analysis. The values expressed as percentage were compared using chi square test among all groups in both seasons separately as well as between the seasons. The parameters which were expressed as mean \pm SEM were statistically compared via one way ANOVA test with Tukey adjustment among all groups. Unpaired Student's T-test was used to compare the embryonic/fetal heart rates on day 25 and 45 post-mating with the groups.

\section{RESULTS AND DISCUSSION}

The estrus induction rate (\%) was observed to be nonsignificantly greater $(\mathrm{P}>0.05)$ during breeding season than out-of-breeding season (Table 1). Contrary to the present findings lesser estrus response rate had been reported previously using GPG/Ovsynch protocol during nonbreeding season (Almadaly et al., 2016; Lone et al., 2016; Martemucci et al., 2010). The poor response of ewes to GPG treatment during out-of-breeding season might be due to failure of the hormonal protocol and/or male effect to rebound from deep anestrus (Almadaly et al., 2016). The use of GPG protocol during typical breeding season reported findings similar to current study but more scattered ovulations in Farfara ewes (Ali et al., 2009). In contrast, lesser (Ashmawy, 2011; Hashem et al., 2015) and greater (Abu El-Ella et al., 2016; Oliveira et al., 2009) estrus induction rate had been reported using GPG protocol during breeding season. The differential outcomes of the GPG protocol during breeding season could be attributed to types of hormones used, the depth of anestrus and breed differences. The response to GnRH is not always similar and it mainly relies on the stage of the estrous cycle at the time of its application (Kumar et al., 2016). The inability of first GnRH injection to induce ovulation and formation of corpus luteum for action of $\mathrm{PGF}_{2 \alpha}$ might be a reason for the poor estrus induction rate in GPG protocol (Hashem et al., 2015).

The interval $(\mathrm{h})$ between end of treatment and onset of estrus was significantly greater $(\mathrm{P}<0.001)$ during out-ofbreeding season than breeding season (Table 1). Husein and Kridli (2003) found similar interval to onset of estrus using P4 sponges with GP protocol in anestrus Awassi ewes during non-breeding season. However, inclusion of P4 sponges prior to GP protocol might be responsible for better estrus response due to $\mathrm{P} 4$ priming of CNS. The longer interval to onset of estrus using GPG protocol 
Table 1: Effect of estrus synchronization protocols on the reproductive traits of crossbred ewes during atypical and typical breeding seasons

\begin{tabular}{|c|c|c|c|c|}
\hline \multirow{3}{*}{ Reproductive traits } & \multicolumn{4}{|c|}{ Treatment groups } \\
\hline & \multicolumn{2}{|c|}{$\begin{array}{c}\text { Out-of-breeding season } \\
\end{array}$} & \multicolumn{2}{|c|}{ Breeding season } \\
\hline & $\begin{array}{l}\text { Group I (Control) } \\
(n=15)\end{array}$ & $\begin{array}{l}\text { Group II (Treatment) } \\
(n=15)\end{array}$ & $\begin{array}{l}\text { Group III (Control) } \\
(\mathrm{n}=15)\end{array}$ & $\begin{array}{l}\text { Group IV (Treatment) } \\
(n=15)\end{array}$ \\
\hline Estrus induction rate $(\%)$ & - & $53.33(8 / 15)$ & $60.00(9 / 15)$ & $66.67(10 / 15)$ \\
\hline $\begin{array}{l}\text { Interval between end of treatment } \\
\text { and onset of estrus (h) }\end{array}$ & - & $44.75 \pm 5.59^{a}$ & - & $58.20 \pm 2.80^{\mathrm{b}}$ \\
\hline Estrus duration $(\mathrm{h})$ & - & $23.25 \pm 2.10$ & $24.67 \pm 2.33$ & $26.67 \pm 2.47$ \\
\hline $\begin{array}{l}\text { Pregnancy rate on day } 25 \text { post- } \\
\text { mating }(\%)\end{array}$ & $13.33^{\mathrm{a}}(2 / 15)$ & $87.50^{\mathrm{b}}(7 / 8)$ & $88.89^{\mathrm{b}}(8 / 9)$ & $90.0^{\mathrm{b}}(9 / 10)$ \\
\hline $\begin{array}{l}\text { Pregnancy rate on day } 45 \text { post- } \\
\text { mating }(\%)\end{array}$ & $6.67^{\mathrm{aA}}(1 / 15)$ & $62.50^{\mathrm{B}}(5 / 8)$ & $66.67^{\mathrm{B}}(6 / 9)$ & $70.0^{\mathrm{b}}(7 / 10)$ \\
\hline $\begin{array}{l}\text { Embryonic losses (between day } \\
25-45 \text { post-mating) }\end{array}$ & $1(50.0 \%)$ & $2(28.57 \%)$ & $2(25.0 \%)$ & $2(22.22 \%)$ \\
\hline Lambing rate $(\%)$ & $6.67^{\mathrm{aA}}(1 / 15)$ & $62.50^{\mathrm{B}}(5 / 8)$ & $66.67^{\mathrm{B}}(6 / 9)$ & $70.0^{\mathrm{b}}(7 / 10)$ \\
\hline Prolificacy (\%) & $100.0(1 / 1)$ & $100.0(5 / 5)$ & $100.0(6 / 6)$ & $100.0(7 / 7)$ \\
\hline Fecundity (\%) & $6.67^{\mathrm{aA}}(1 / 15)$ & $62.50^{\mathrm{B}}(5 / 8)$ & $66.67^{\mathrm{B}}(6 / 9)$ & $70.0^{\mathrm{b}}(7 / 10)$ \\
\hline
\end{tabular}

Values bearing superscripts A and B differ significantly between groups within rows $(\mathrm{P}<0.01)$; Values bearing superscripts a, b, c and d differ significantly between/among groups within rows $(\mathrm{P}<0.001)$; Values expressed as percentage and mean \pm SEM not bearing superscript vary non-significantly within rows $(\mathrm{P}>0.05)$.

during out-of-breeding season was suggestive that second GnRH injection could be given later near the onset of estrus for better ovulation synchrony to improve the fertility (Martemucci et al., 2010). A lesser (Hashem et al., 2015; Kulaksiz et al., 2013) and greater (Abu El-Ella et al., 2016) interval to onset of estrus than present findings had been observed previously using GPG protocol during breeding season. The variability in response of first GnRH injection and occurrence of luteolysis at the time when largest follicle is in the regressing stage might be cause of subsequent late onset of estrus and delayed ovulation (Menchaca and Rubianes, 2004).

The mean duration of estrus in the ewes varied nonsignificantly $(\mathrm{P}>0.05)$ among different groups (Table 1$)$. The mean estrus duration of ewes using GPG protocol for estrus synchronization during typical breeding season was similar to previous findings (Hashem et al., 2015; Kulaksiz et al., 2013).However, longer estrus duration $(40.00 \pm 16.80 \mathrm{~h})$ was observed in Rahmani ewes (Abu ElElla et al., 2016) using GPG protocol in breeding season. In contrast, Ali et al. (2009) observed estrus duration of $19.0 \pm 2.1 \mathrm{~h}$ in Farfara ewes using GPG protocol which was quite lesser than present study. The observation of almost similar duration of estrus in the ewes irrespective of the treatment groups might be due the poor prolificacy of the breed and almost similar number of ova present at the induced estrus; however, slightly longer estrus duration during breeding season might be due to increased ovarian activity.

The pregnancy detected through USG (5.0-6.0 MHz) on day 25 and 45 post-mating was significantly $(\mathrm{P}<0.001)$ lesser in control group during out-of-breeding season than treatment groups as well as control group of breeding season. The pregnancy rate on day 45 in Group I also followed the same pattern and differed significantly than Group II $(\mathrm{P}<0.01)$, III $(\mathrm{P}<0.01)$ and IV $(\mathrm{P}<0.001)$. The pregnancy rate on day 25 and 45 post-mating varied nonsignificantly $(\mathrm{P}>0.05)$ among Group II, III and IV (Table 1). The pregnancy rate of ewes underwent GPG protocol during typical breeding season was in concurrence with Abu El-Ella et al. (2016). On the other hand, Hashem et al. (2015) revealed 100\% conception rate using GPG protocol in Barki and Rahmani crossbred ewes. However, lesser pregnancy rates were observed in other studies viz. $50 \%$ and $35.7 \%$ post timed $\mathrm{AI}$ and natural mating in Karagouniko ewes (Deligiannis et al., 2005); 50\% in Farfara ewes (Ali et al., 2009) and 33.3\% and 46.6\% after timed AI using GPG protocol (Martínez et al., 2013). 
The embryonic losses i.e. 1 (50.0\%), 2 (28.57\%), 2 $(25.0 \%)$ and $2(22.22 \%)$ were also noticed in Group I, II, III and IV, respectively between day 25 to day 45 post-mating evidenced by absence of embryonic vesicle, amniotic fluid and absence of detectable heart rate in fetuses on day 45 post-mating. Embryonic losses noticed between day 25 to 45 post-mating were consistent with the findings of Schrick and Inskeep (1993) with the absence of heart beat and embryonic vesicle on day 45 indicating the embryonic wastage. The reason for occurrence of more false positives through trans-rectal B-mode USG at earlier might be due to early diagnosis of pregnancy or embryonic death at later stages of gestation (Fowler and Wilkins, 1984; Buckrell, 1988). The findings of the present study indicated that early pregnancy diagnosis could also be a mean for assessment of late embryonic deaths occurring post maternal recognition of pregnancy (MRP).

The fertility (\%) on the basis of the number of animals mated varied significantly in Group I than Group II $(\mathrm{P}<0.01)$, III $(\mathrm{P}<0.01)$ and IV $(\mathrm{P}<0.001)$ but there was no significant $(\mathrm{P}>0.05)$ difference among Group II, III and IV (Table 1). The crossbred ewes under the study are usually known to be less prolific and rarely give birth to twins and thus no twinning was observed in any ewe. While, no twinning was found in ewes treated and kept as control so the prolificacy in each group was 100\% (Table 1). However, the fecundity (\%) was also significantly lesser in Group I than Group II $(\mathrm{P}<0.01)$, III $(\mathrm{P}<0.01)$ and IV $(\mathrm{P}<0.001)$ which varied non-significantly $(\mathrm{P}>0.05)$ among Group II, III and IV (Table 1). Martemucci and Alessandro (2010) recorded $80 \%$ fertility following GPG protocol during non-breeding season. However, the fertility (\%) was lesser in other studies viz. 50\% in Farfara ewes (Ali et al., 2009); 20\% in Awassi ewes (Titi et al., 2010) and $35.7 \%$ in fat-tailed ewes (Kulaksiz et al., 2013) during breeding season using GPG protocol. Hashem et al. (2015) observed 100\% lambing rate in Barki and Rahmani crossbred ewes using GPG protocol in breeding season. The study was also supported by findings of Ali et al.(2009) and Hashem et al.(2015) with no twinning in Farfara and crossbred ewes respectively, subjected to GPG protocol in breeding season.

The average plasma $\mathrm{P} 4$ concentrations $(\mathrm{ng} / \mathrm{mL})$ on day 0 varied non-significantly $(\mathrm{P}>0.05)$ among all groups (Fig. 2 ). The luteal function of the ewes underwent treatment was maintained equally as evidenced by Plasma P4 concentration on day 14, 25 and 45 post-mating which varied non-significantly ( $\mathrm{P}>0.05$ ) among all groups (Fig. 2). The values of plasma $\mathrm{P} 4$ were comparable with Almadaly et al. (2016) on day 0 while lower than Husein and Kridli (2003). The serum P4 concentration $(\mathrm{ng} / \mathrm{mL})$ on day 21 and 24 post insemination were comparable to the present study in Rahmani ewes subjected to different modalities of GPG protocol during breeding season (Ashmawy, 2011). P4 concentration in Rahmani ewes underwent GPG protocol during breeding season were almost similar to the present study on day of start of treatment and day 18 and 30 post-mating (Ashmawy, 2011).

The embryonic/fetal heart rates done to assess the embryonic/fetal viability on day 25 and 45 post-mating vary non-significantly $(\mathrm{P}>0.05)$ among all groups (Table 2 ). The findings of the present study regarding embryonic/ fetal heart rate were in contrast to other studies where higher ovine fetal heart rates were observed by other workers (Aiumlamai et al., 1992; Godfrey et al., 2010). The decrease in fetal heart rate with increase in gestational age was consistent with other reports in sheep (Aiumlamai et al., 1992; Godfrey et al., 2010). However, the difference in embryonic/fetal heart rate could be attributed to breed difference and other climatic factors.

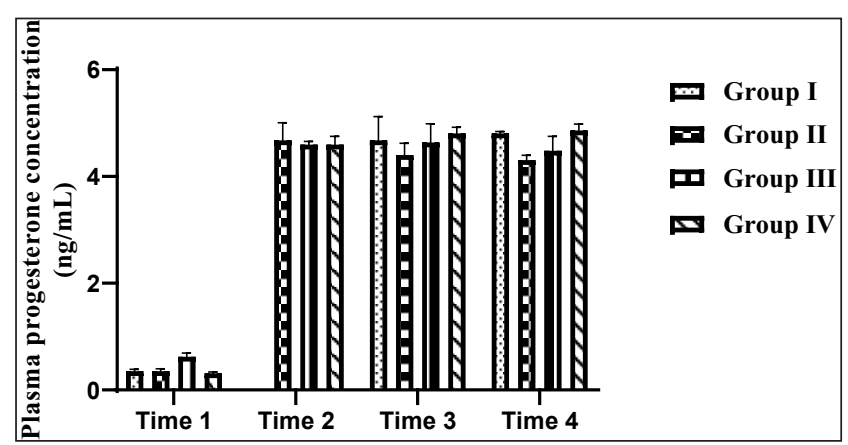

Fig. 2: The effect of estrus synchronization protocol during out-of-breeding and breeding season on plasma progesterone concentration $(\mathrm{ng} / \mathrm{mL})$ in crossbred ewes at different time intervals which included: time 1 (at the start of experiment i.e day 0 ), time 2 (day 14 post-mating), time 3 (day 25 post-mating) and time 4 (day 45 post-mating). Group I and III served as control during out-of-breeding and breeding season, respectively. Group II and IV stands for Ovsynch/ GPG protocol during out-ofbreeding and breeding season, respectively.

The presence of anechoic fluid followed by hypoechoic embryo proper in the lumen of uterus was considered to be the first and foremost reliable indication of pregnancy 
Table 2: Embryonic/fetal heart rate per min (Mean \pm SEM) on day 25 and 45 post-mating in crossbred ewes subjected to estrus synchronization during atypical and typical breeding season

\begin{tabular}{llll}
\hline Season & & $\begin{array}{l}\text { Embryonic heart rate on day 25 } \\
\text { post-mating (beats per min) }\end{array}$ & $\begin{array}{l}\text { Fetal heart rate on day 45 post- } \\
\text { mating (beats per min) }\end{array}$ \\
\hline \multirow{2}{*}{ Out-of-breeding season } & $\begin{array}{l}\text { Group I (Control) } \\
(\mathrm{n}=15)\end{array}$ & $127.00 \pm 1.00$ & $123.50 \pm 0.50$ \\
& $\begin{array}{l}\text { Group II (Treatment) } \\
(\mathrm{n}=15)\end{array}$ & $129.29 \pm 1.55$ & $126.80 \pm 1.24$ \\
& $\begin{array}{l}\text { Group III (Control) } \\
(\mathrm{n}=15)\end{array}$ & $128.38 \pm 1.00$ & $126.00 \pm 1.06$ \\
Breeding season & $\begin{array}{l}\text { Group IV (Treatment) } \\
(\mathrm{n}=15)\end{array}$ & $132.44 \pm 1.89$ & $129.71 \pm 2.25$ \\
\hline
\end{tabular}

Mean \pm SEM not bearing superscripts did not vary significantly $(\mathrm{P}>0.05)$ among groups on day 25 and 45 post-mating, respectively as well within group on day 25 and 45 post-mating.

(Gearhart et al., 1988). The findings of present study were in accordance with Buckrell (1988) and GonzalezBulnes et al. (2010) who found that imaging of embryo proper, heartbeat of embryo and placentomes might be possible from day 18, 18-23 and 26-28 days of gestation onwards in sheep, respectively. The variation in the time of the detection of embryo proper, embryonic heartbeat, placentomes might be due to differences in frequency of scanning, breed, litter size, and skill of the operator (Fridlund et al., 2013). The multiple assessment of pregnancy in ewes using USG could be a mean of detection of embryonic viability, fetal number count, late embryonic or fetal wastage and impending dystocia (Buckrell, 1988; Kähn, 1992).

\section{CONCLUSION}

The findings of the present study showed that Ovsynch/ GPG protocol was successful in estrus induction during breeding as well as out-of-breeding season in crossbred ewes. The results in terms of estrus induction rate (\%), pregnancy and subsequent fertility were pronounced in out-of-breeding season in animals treated than those not underwent estrus synchronization. However, the estrus synchronization protocol did not improve prolificacy and fecundity which could be due to the less prolificacy of breed under study. However, the use of protocol during out-of-breeding season showed promising results but not in breeding season, so the cheaper estrus synchronization protocol requiring no expertise in application could be advised for the improvement of reproductive outcomes in crossbred ewes during out-of-breeding season also to ascertain increased economic returns of poor farmers. The multiple assessments of ewes during the first half of the gestation using USG could be a mean of detection of embryonic viability, fetal number count, late embryonic or fetal wastage and impending dystocia.

\section{REFERENCES}

Abecia, J.A., Forcada, F. and González-Bulnes, A. 2011. Pharmaceutical control of reproduction in sheep and goats. Vet. Clin. N. Am. Food. A., 27(1): 67-79.

Abu El-Ella, A.A., Teleb, D.F., Abdel-Hafez, M.A.M. and Deghedy, A.M. 2016. Appraisal of different protocols for estrus synchronization in local Rahmani sheep. Egypt. J. Sheep Goat Sci., 65(4121): 1-16.

Aiumlamai, S., Fredriksson, G. and Nilsfors, L. 1992. Real-time ultrasonography for determining the gestational age of ewes. Vet. Rec., 31: 560-562.

Ali, A., Hayder, M. and Saifelnaser, E.O.H. 2009. Ultrasonographic and endocrine evaluation of three regimes for oestrus and ovulation synchronization for sheep in the subtropics. Reprod. Domst. Anim., 44(6): 873-878.

Almadaly, E., Ashour, M., El-Kon, I., Heleil, B. and Fattouh, E.S. 2016. Efficacy of various synchronization protocols on the estrus behavior, lambing rate and prolificacy in rahmaniegyptian ewes during the non-breeding season. Asian J. Anim. Vet. Adv., 11(1): 34-43.

Ashmawy, T.A.M. 2011. Timing ovulation in ewes treated with ovsynch different times of PGF $2 \alpha$ injection during the breeding season. Iranian J. App. Anim. Sci., 1(1): 23-30.

Buckrell, B.C. 1988. Application of ultrasonography in reproduction in sheep and goats. Theriogenology, 29: 71-84. 
Deligiannis, C., Valasi, I., Rekkas, C.A., Goulas, P. and Theodosiadou, E. 2005. Synchronization of ovulation and fixed time intrauterine insemination in ewes. Reprod. Domest. Anim., 40: 6-10.

Fowler, D.G. and Wilkins, J.F. 1984. Diagnosis of pregnancy and number of fetuses in sheep by real-time ultrasonic imaging. I. Effects of number of foetuses, stage of gestation, operator and breed of ewe on accuracy of diagnosis. Livest. Prod. Sci., 11: $437-450$.

Fridlund, C., Humblot, P., Bage, R. and Soderquist, L. 2013. Factors affecting theaccuracy of pregnancy scanning in ewes. Vet. Rec., 173(24): 606-606.

Gearhart, M.A., Wlngfield, W.E., Knight, A.P., Smith, J.A. and Dargatz, D.A. 1988. Real-time ultrasonography for determining pregnancy Status and viable fetal numbers in ewes. Theriogenology, 30(2): 323-337.

Godfrey, R.W., Larson, L., Weis, A.J. and Willard, S.T. 2010. Evaluation of ultrasonography to measure fetal size and heart rate as predictors of fetal age in hair sheep. Sheep Goat Res. J., 25: 60-65.

Gonzalez-Bulnes, A., Pallares and Vazquez, M.I. 2010. Ultrasonographic imaging insmall ruminant reproduction. Reprod. Domest. Anim., 45: 9-20.

Hashem, N.M., El-Zarkounyb, S.Z., Tahaa, T.A. and AboElezzaa, Z.R. 2015. Oestrous response and characterization of the ovulatory wave following oestrous synchronization using PGF $2 \alpha$ alone or combined with GnRH in ewes. Small Ruminant Res., 129: 84-87.

Husein, M.Q. and Kridli, R.T. 2003. Effect of progesterone prior to GnRH-PGF2 $\alpha$ treatment on induction of estrus and pregnancy in anestrous Awassi ewes. Reprod. Domest. Anim., 38: 228-232.

Kähn, W. 1992. Ultrasonography as a diagnostic tool in female animal reproduction. Anim. Reprod. Sci., 28: 1-10.

Kulaksiz, R., Ucar, O. and Daskin, A. 2013. Effects of FGA sponge and Ovsynch based protocols on reproductive performance of fat-tailed ewes during the breeding season. Kafkas Univ. Vet. Fak. Derg., 19(4): 629-633.
Kumar, B.H., Bramhaiah, K.V., Srinivas, M., Ekambaram, B. and Dhanalakshmi, N. 2016. Effect of estrus synchronization by progesterone sponge along with PMSG on estrus response and fertility in Nellore Jodipi ewe lambs. Theriogenology Insight, 6(3): 135.

Lone, F.A., Malik, A.A., Khatun, A., Shabir, M. and Islam, R. 2016. Returning of cyclicity in infertile Corriedale sheep with natural progesterone and $\mathrm{GnRH}$ based strategies. Asian Pac. J. Reprod., 5(1): 67-70.

Maraček, R., Vlčková, J., Kal'atová, D., Sopková, K. and Klapáčová, I. 2009. Effect of assisted oestrus on the ovulation rate and reproductive performance of Tsigai sheep. Slovak $J$. Anim. Sci., 41(1): 51-55.

Martemucci, G. and D Alessandro, A.G. 2010. Estrous and fertility responses of dairy ewes synchronized with combined short term GnRH, PGF2 $\alpha$ and estradiol benzoate treatments. Small Ruminant Res., 93: 41-47.

Martínez, T., Montañez, V., Ley De, C.A., Izaguirre, F. and Velazco, Z. 2013. Effect of GnRH and D-Chloprostenol application on pregnancy and prolificacy rates on Pelibueyewes. Revista MVZ Córdoba, 18: 3612-3617.

Menchaca, A. and Rubianes, E. 2004. New treatments associated with timed artificial insemination in small ruminants. Reprod. Fertil.Devel.,16(4): 403-413.

Oliveira, M.E.F., Rodrigues, L.F.S., Almeida, O.M., Cordeiro, M.F. and Moura, A.C.B. 2009. Efficiency of the Ovsynch protocol in Santa Inês ewes. Archivos de Zootecnia, 58(222): 281-284.

Scherick, F.N. and Inskeep, E.K. 1993. Determination of early pregnancy in ewes utilizing trans-rectal ultrasonography. Theriogenology, 40(2): 295-306.

Titi, H.H., Kridli, R.T. and Alnimer, M.A. 2010. Estrus synchronization in sheep andgoats using combinations of $\mathrm{GnRH}$, progestagen and prostaglandin F2 $\alpha$. Reprod. Domest. Anim., 45: 594-599. 
